Article

\title{
Leadership and Effective Institutional Economics Design in the Context of Education Reforms
}

\author{
Wadim Strielkowski ${ }^{1}{ }^{*}$, Vyacheslav Volchik ${ }^{2}$, Artyom Maskaev ${ }^{2}$ and Pavel Savko ${ }^{2}$ \\ 1 Department of Trade and Finance, Faculty of Economics and Management, Czech University of Life Sciences \\ Prague, Kamýcká 129, 16500 Prague 6, Prague, Czech Republic \\ 2 Department of Economic Theory, Faculty of Economics, Southern Federal University, Bolshaya Sadovaya str. \\ 105, 344006 Rostov-on-Don, Russia; volchik@sfedu.ru (V.V.); maskaev@sfedu.ru (A.M.); savko@sfedu.ru (P.S.) \\ * Correspondence: strielkowski@pef.czu.cz
}

Received: 30 November 2019; Accepted: 27 March 2020; Published: 3 April 2020

check for updates

\begin{abstract}
Nowadays, the most typical reforms in higher education are conducted through the reorganization of universities either in the form of a merger, acquisition, or new status attainment. As a result, universities which educate local leaders for their respective national economies and have a profound impact on the regional economic development, as well as the composition of the labor market and intellectual potential, often encounter negative economic outcomes. The reforms that are imposed by the policymakers "from above" often hamper the development of universities and prevent them from fulfilling their roles described above. The process of reforming higher education in Russia is in many ways similar to the changes in the higher education systems of other European countries, in particular in post-Communist transition economies. Firstly, this process went through the integration into the global market of educational services. Secondly, it proceeded with the rethinking of the role of the university as a self-sustainable business organization. Thirdly, it was concluded by an increase in the demand and accessibility of education using the advancements offered by the digital technologies. Our paper argues that focused and well-balanced economic institutional design might be required for the sustainable development of reorganized leading universities. The project perspective implies that it is necessary to develop an institutional design in relation to what the organization seeks to achieve (either as its regulator or reformer) and how it intends to achieve these goals. In connection with the foregoing, we propose the following principles of designing effective institutions for the sustainable development of reorganized universities: (i) preservation of education as a "mixed" good (i.e., one that has the features of both public and private goods); (ii) transparency of decision making; (iii) complementarity of institutional change; and last but not least (iv) reduction in transaction costs.
\end{abstract}

Keywords: higher education; institutional economics; universities; new public management; institutional changes; complementarity; transaction costs

JEL Classification: B52; I21; O10

\section{Introduction}

In the 21st century, higher education and the research and development (R\&D) sector worldwide are undergoing profound changes (Möller 2018; Zapp and Ramirez 2019). Some of the major features of this transformation include the changes in the demographic characteristics of students, rapidly altering needs of actors, scientific and technological progress and the digital economy, labor market demands, as well as a plethora of other factors (Coates et al. 2016; Payne et al. 2017; Ren et al. 2017; Boyce et al. 2019). All of these factors have led universities and higher educational institutions (HEIs) 
to review the existing ideas about organizational mechanisms, their geography of commercial activity, as well as their ways of teaching and researching as well as providing a satisfactory quality of education.

Reforms of higher education and the implementation of national projects supported by extra funding related to those reforms represent a multi-faceted process that includes the reorganization of universities among other issues (Bileviciute et al. 2019). The ongoing changes in the field of university mergers and acquisitions are related to the fact that, according to the regulators of this field, old models of higher education that are based on traditions and stability will sooner or later be supplemented, if not supplanted, by new models embracing organizational innovations, behavioral patterns, responsibility, as well as adaptation.

Moreover, the "verticality" of the reforms is reflected not only in administrative and managerial processes, but also in trust, culture, academic freedom, and existence of the important institutions of the academic community. In this paper, we argue that for the sustainable development of reorganized universities, a focused institutional design is required. With regard to the above, we study the mechanisms of reorganization of universities and propose principles for designing effective institutions for the sustainable development of reorganized universities.

Our paper focuses on the leadership and effective institutional economics design in the context of education reforms in the Russian Federation. The paper is structured as follows: Section 2 discusses the theoretical framework and the methodology, Section 3 contemplates on the issue of transaction costs of actors of reorganized universities, and Section 4 discusses how the effective institutions for reorganized universities can be derived. In particular, it focuses on the principle of preservation of education as a "mixed" good, the principle of complementarity of institutional change, as well as on the principle of transparency in decision making and the diversity of incentives. Finally, Section 5 closes the paper, providing conclusions and policy implications.

\section{Methodology}

Generally, it becomes quite apparent that the whole theoretical framework for the reorganization and merging of universities and higher education institutions (HEIs) can be viewed through the prism of neoliberalism.

Speaking about "neoliberalism", we were advised to be more precise about this terms which clearly deserves a good definition here, since any economic analysis appears to be meaningless without a definition and critique of the economic structures of neoliberalism in the political, cultural, economic, and governance context of the higher education, including the funding of HEIs and the origins of the funding sources in the Russian Federation.

For example, Taysum (2019) defined neoliberalism as the force that led to the world's economic and financial crisis of 2008 in the Western economies. However, one can see that this is not the same "neoliberalism" that exists in the Russian Federation nowadays. Surely, there has been a shift from centrally planned bureaucracy to a market economy which came as a shock in 2008 and led to many structural issues as well as impacting on many sectors of economic and public life, causing many problems for HEIs in the Russian Federation. Nevertheless, Hemment (2009) argued that Russia moved from being a "laboratory" for liberal economic reforms in the 1990s to assuming a demonstratively hostile stance towards liberal policies in the 2000s. With regard to the above, Rutland (2013) pointed out that "neoliberalism" was a body of ideas that played an independent causal role in Russia's post-Soviet transition. On the contrary, Ganev (2005) stated that both advocates and critics of neoliberalism are exaggerating its importance in shaping the post-socialist transition. In addition, Clément (2019) argued that the Russian perception of "neoliberalism" is shaped by the historical development when the ultraliberal reforms led to mass precariousness and social disorientation.

Hence, we would adapt a discussion from Rutland (2013) that sees the neoliberalism in the Russian Federation as a broad political philosophy that went through a series of metamorphoses marking the prominent role for the state in economic strategy and meaning that in the 21st century Russia has moved well beyond a "neoliberal" approach to economic development. 
In general, the process of reforming higher education in the Russian Federation is in many ways similar to the changes that have taken place in higher education systems in the West (Jongbloed et al. 2008; De Boer et al. 2008; Loomis and Rodriguez 2009; Tahar and Boutellier 2013; Holmberg and Hallonsten 2015; Babintsev et al. 2016). The changes were caused by a decentralization that the Russian government wished to empower higher education in a transition from communism to the reformation of the social contract and governance processes and practices. The main global trends in Russia and in the world include: firstly, integration into the global market for educational services; secondly, rethinking the role of the university as a business (self-reliant) organization; and thirdly, an increase in the demand and accessibility of education through digital technologies (Valeeva and Gafurov 2017; Bogoviz et al. 2018; Francesconi et al. 2019). At the same time, there exists a certain paradox. This paradox is about the fact that the functioning of the university within the framework of the concept of new management in the public sector implies work in market or quasi-market conditions. This process should be accompanied by the decentralization of managerial hierarchies and increased autonomy of universities. Moreover, it goes hand in hand with a decrease in academic freedoms and tightening of control for the activities of the university through a system of targets (Volchik et al. 2018).

The main global trends in the reform of higher education in Russian Federation can be summarized in six main steps (shown at the left in Figure 1 that follows). These changes constitute two more general trends: the globalization of education and the consideration of the university as a service company through the prism of the concept of new public sector management (NPM). An attempt to reduce government spending through rhetoric of market efficiency and creating a global educational market in which these quasi-market structures are forced to compete to attract highly mobile, international students, all might lead to a global and profound transformation of universities as the institution (De Boer et al. 2007).

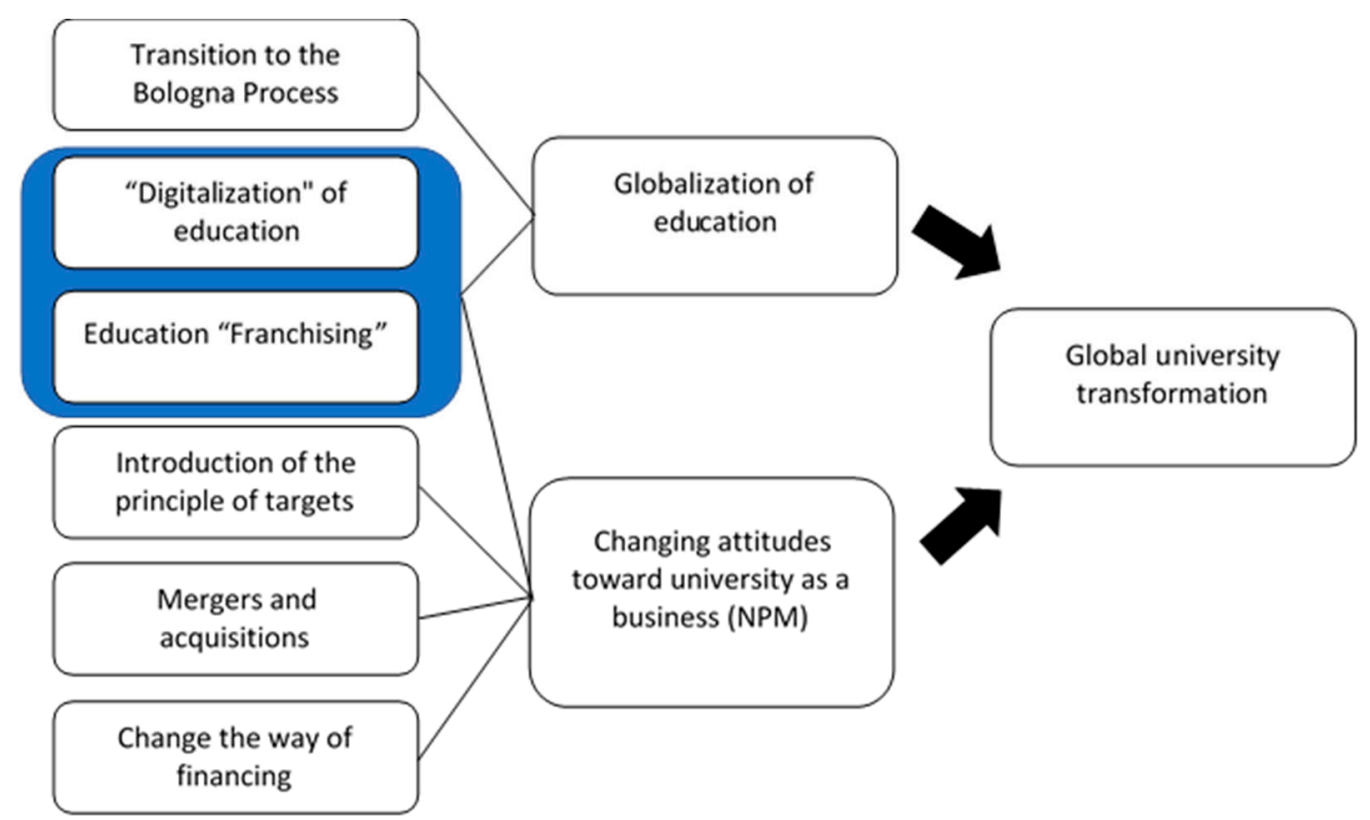

Figure 1. Main steps in the transformation of higher education in the Russian Federation. Source: Own results.

Our research is based on two trends from the above list which are an example of related technological and institutional changes, such as digitalization and franchising in the field of higher education. It is worth noting that without the digital revolution which increased the speed of transmission and processing of information, and hence reduced transaction costs, the process of globalization would have been impossible. "Franchising" of higher education represents a consequence 
of the development of information technology and the transition to a hyper-information society when the new forms of distance education and the excessive availability of information can create the illusion of mastering expert competencies. Digitalization allows streaming lectures in video or allows professors and students to interact in the virtual environments, but not everyone is ready for this. Many young people who do not spend much time "in real life" (IRL) and rather prefer playing video games or interacting with others of social network platforms confess that they would have preferred being lectured in real classrooms and in real universities. Sometimes this is just a feature of habit and sometimes this is required due to the difficulties with personal time management when left studying online from the comforts of one's home.

The digitalization program of higher education in Russia employs franchising-a business model approach when the head office opens local branches or includes existing organizations in its network that copy and fulfill the requirements of the head university. The transition to the format of video lectures, the expansion of the number of students and the reduction in the number of faculty members (or transfer to part-time staff and a short-term contract) is carried out in order to reduce costs and increase profits (Ansel 2008). The negative aspects of this trend might be lowering the quality of education since online education represents quite a new trend not applicable to all fields and to all people. The undoubted positive aspects of this approach can be considered as an increase in the accessibility of higher education, but the opportunity costs of destroying local academic communities and concentrating resources (both material and intellectual) in several metropolitan universities should also be considered. In order to support this argument, one has to understand the specifics of Russian universities. Unlike their Western counterparts, who communicate with each other via the Internet and conduct research projects from their respective countries across the globe, Russian academics are less mobile and prefer to congregate in local academic communities, often without many contacts with each other. This might be attributed to the legacy of the Soviet Union when many world-class laboratories and research institutions had to work in secrecy (similar to the Manhattan project in the United States in the 1940s and 1960s). As a result, Russian higher education institutions are based on the so-called "schools" centered around prominent researchers and their students often working for generations on one narrow topic (Rodionov et al. 2016; Kotiev et al. 2017). Another issue is the limited knowledge of foreign languages and international ties that Russian academics are notorious for.

The possibilities of technological development are reflected in the transformation of existing HEIs, when institutions traditionally based on the principles of optimization, efficiency, and planning are being exogenously replaced by the traditional "Humboldt-type" university that represents the return to the so-called "classical university" that should not seek how to commercialize its research and education activities but rather concentrate on educating the students and producing research output in return for hefty state funding.

Thus, the new management policy in the public sector becomes one of the varieties of indicative planning, and, therefore, takes over the main shortcomings of all systems that are not based on spontaneous market interaction, There is a need for non-economic coercion, as well as adaptation to the set indicators, which inevitably leads to a decrease in the quality of services provided. Attempts to set targets and performance indicators in relation to higher education are detrimental and meet with opposition from academics. An example of such an arrangement is the so-called "Project 5-100", aimed at getting at least 5 leading Russian universities among the first $100 \mathrm{HEIs}$ in one of the world's top university rankings. In order to achieve this objective, 21 promising Russian universities were selected and provided extra funding and institutional support. It is expected that they will make their way to the top HEIs rankings within a few years (Ministry of Science and Higher Education of the Russian Federation 2020). Participation in this program might replace the goal of improving the quality of higher education and distort the real needs of a higher educational institution, forcing resources to be directed towards achieving indicators that improve the university ranking (Collini 2012). Moreover, it is not clear which ranking to follow-there 
are ones from China, the United States, or the United Kingdom, with attempts to build local Russian rankings too.

The development of the higher education management system and educational policy leads to the copying of managerial techniques not previously used in the public sector (Ferlie et al. 2008; Schubert 2009). Educational institutions should, in accordance with these principles, gain greater autonomy, especially when it comes to financial freedom. The role of the policymakers comes down to defining global goals, moving from line-by-line financing to general, when, depending on the achievement of the required results, a decision is made on the allocation of resources. Currently, only a handful of universities in Russia have sufficient funding to implement their own strategies. The transition to general and per capita financing in the context of demographic and economic crises has led to increased competition for students.

Initiatives of ongoing reforms in higher education in Russia are put forward at the federal and regional levels. Regional lawmaking in the field of integration of science and education, along with the reproduction of relevant federal norms, reflects the legal initiatives of various administrative regions of the Russian Federation. The problem is that they are often fragmented and do not offer a single integrated approach targeted at solving the key problems and creating legal mechanisms for the promotion of Russian science and education (Shersheva 2017).

NPM is a powerful tool for improving the effectiveness of public administration but can only seldomly be used in science. The imposition of these non-academic models on universities creates great tension between research and administration. Here is where a dilemma of inefficiency arises due to the lack of reliable market indicators and the use of various forms of rationing Thence, universities should learn how to use the toolbox of high-quality instruments that might help to deliver their visions, mission and strategic plans which are linked to the sustainable development goals and supported by the appropriate government policies.

All of the above very often cannot yield satisfactory results based on organizational and institutional contexts. These concepts are based on the historical, political, as well as cultural aspects of the institutional environment of the national economic order (Tambovtsev 2015). Therefore, the achievement of effective indicators of the development of higher education can be considered in the context of regulatory failures, arising on the one hand, as a result of imperfect information, and on the other, ignoring the evolutionarily established informal institutions and self-regulatory mechanisms in the university community which leads to a limitation of academic freedoms and erosion fundamental social values.

\section{Transaction Costs of Actors of Reorganized Universities}

From the perspective of the old institutionalism, the economic behavior of actors is determined by the social context and relevant values. Veblen adhered to this approach, revealing the predominance of the endogenous nature of institutions, as well as their relationship with the cultural factor, behavioral patterns, values, and organizational ethics (Veblen 1899). In this context, a person as a subject of economic relations is considered inextricably from his social environment (Volchik and Oganesyan 2014). Social capital plays a large role in higher education, where, as shown by our survey, the status of an employee in the field of science and education can prevail over wages. Thence, a reciprocal relationship between economic institutions and behavioral patterns that occur during organizational and institutional changes, including during the merger and reorganization of universities, their obtaining special statuses (federal, core, research, etc.). There are nine federal universities in Russia that were created by merging various local state-owned universities in the strategic regions such as Far East, Urals or the Baltic region. In addition, there are so-called "research universities", an elite group of state-owned universities that qualified to receive extra funding and research support in order to get into the world academic rankings. Other universities are represented by state-owned universities without any special state endorsement and private universities. In general, one can observe the trend of consolidation of state-owned universities. At the same time, the system 
of social values acts as a peculiar link mediating institutional changes and providing both direct and feedback between institutions and behavioral patterns.

The first methods for the quantitative metric of transaction costs are reflected in the works of Demsetz (1968); North and Wallis (1986); Stoll and Whaley (1983); Bhardwaj and Brooks (1992); Williamson (1993); and many others. However, the first research of this kind was focused on the United States insurance and investment construction sectors, and not to the public economy sector.

The theory of transaction costs meets obstacles in applied research in connection with the problem of identification and metrics of this type of cost. First of all, in scientific discourse, the problem of units for measuring transaction costs, the possibility of their expression in the monetary value (e.g., hourly wages) or as opportunity costs remains unresolved. In order to assess transaction costs, some researchers have identified their contents with opportunity costs (see e.g., Bigelow et al. 2019; Jouan et al. 2019). Other methodological problems include transaction costs, such as loss of reputation, loss of trust in a supplier, and others that are difficult to express in monetary terms (see e.g., Meinlschmidt et al. 2018; Pesch and Ishmaev 2019).

As an element of the public sector of the economies of developed and developing countries, along with healthcare, the concept of a "quasi market" is applicable to higher education, where factors that are difficult to quantify, in particular, reputation, are crucial (Volchik et al. 2017). In the quasi-market of higher education services, opportunity costs are implicit, and as a result, they are practically impossible to account for. The following forms of opportunity costs can be distinguished: foregone time, earnings and profit.

When choosing a methodology for the quantitative metric of transaction costs of each group of actors, one has to make sure that it is based on the fact that the basic measurements of the actors of a university should reflect, first of all, the characteristics of social interaction which are close in nature to the core values of the university.

Working relationships among faculty, students, and administrative staff are based on two types of relationships: formal (contractual, regulated) and informal (behavioral patterns). In education, in connection with its specifics and excessive bureaucratization, informal relations are clearly traced. An employee, as a rule, performs a large number of tasks not prescribed in her or his job description.

Due to the impossibility of adapting quantitative methods for analyzing transaction costs in corporations to the universities we are studying, we collected primary empirical data using a survey of actors (faculty, administration and students) and 10 in-depth interviews with the faculty members holding managerial positions in the main universities of the Rostov region. For these purposes, a questionnaire was prepared to assess the changes in transaction costs of the actors of the educational process. The questionnaire consisted of five blocks of five questions corresponding to the following categories of transaction costs-information retrieval, negotiation, measurement, property rights, and opportunistic behavior. The research was conducted using the appropriate ethical standards (e.g., non-disclosure agreements were signed, and the responses were anonymized leaving only the gender, age, and other related characteristics to be reported for the academic purposes). We used the snowball convenience sampling to recruit our respondents. All the answers were duly recorded and processed.

Respondents' answers allowed us to identify and formalize their transaction costs, where the processed expert estimates were averaged and attributed fractional values from 0 to 1 for each type of cost which corresponds to an average frequency of answers of $0 \%-100 \%$. Even though it is true that costs are typically expressed in monetary terms (e.g., hourly wages), our methodology of formalizing respondents' transaction costs yields better results when scales (corresponding to \% points) are applied. We employed the data from the non-random (target) sample of 128 faculty members, including administrative personnel, and 250 university students from the Rostov region. The main contingent of the respondents is represented by the actors of the federal (SFedU) and core (DSTU) universities. Figure 2 shows on a concise diagram that lists five types of transaction costs and average frictional values expressed by the three groups of respondents. 


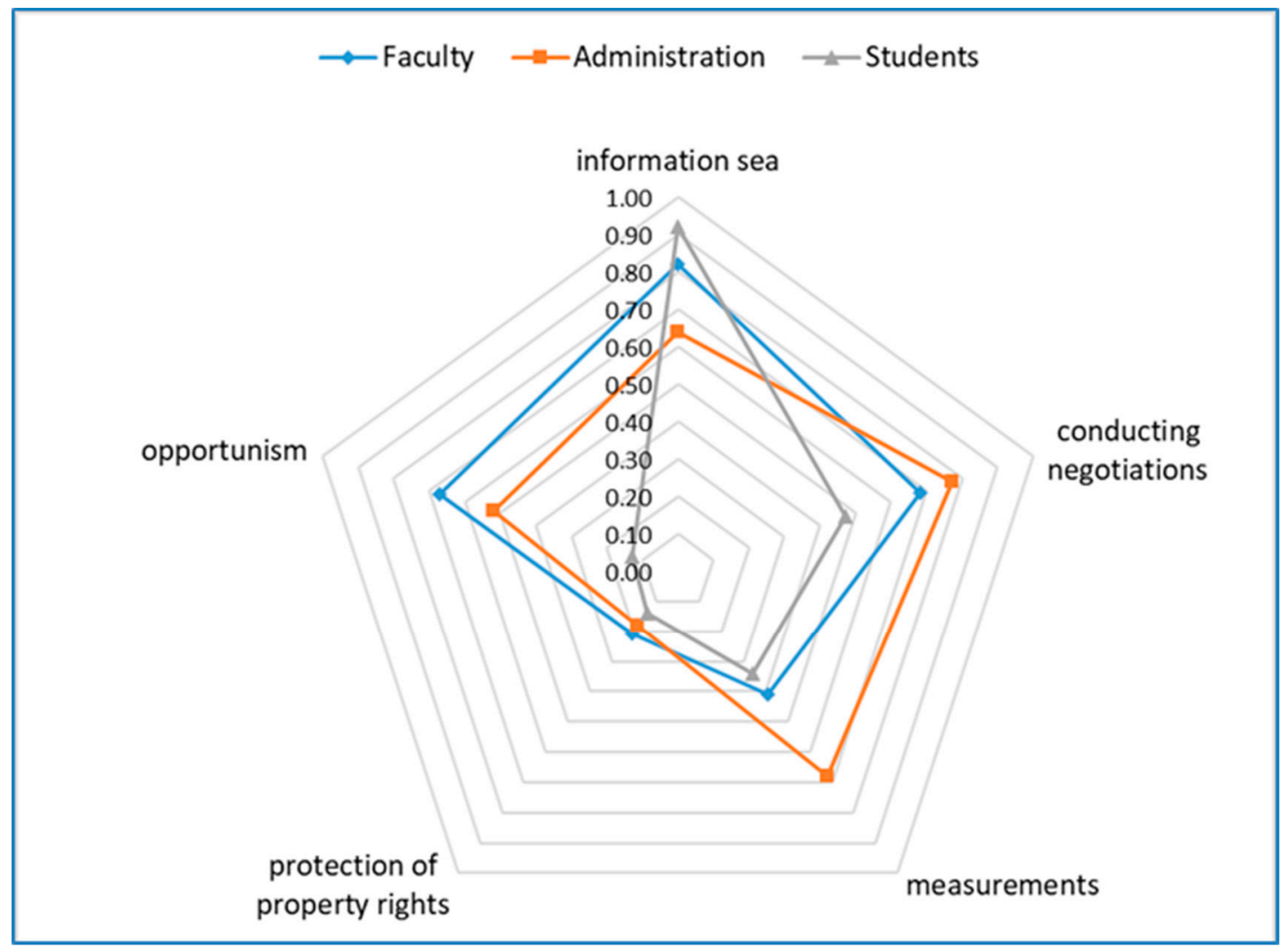

Figure 2. Types and of transaction costs in higher education identified by the respondents. Source: Own results.

Now, let us consider the transaction costs of each group of actors individually. When it comes to students, there is a problem in parts of the educational process. The largest assessment of the transaction costs group is in the search for information, being as high as 0.92. All students appear to face the problem of finding information, including educational materials, statistics, or sources for writing research papers or theses. In particular, students are characterized by high ex ante costs when choosing a place of study, and then the frequency of ex post costs varies along the path of the educational process in relation to each student.

Student negotiation costs were estimated to be at 0.47 . In this section, the problems of choosing a supervisor and project topics, and the choice of specialization were found. In particular, in some universities, in order to choose a scientific adviser for supervising their Master or Ph.D. thesis, students must first complete various assignments, for example, write an essay on the potential supervisor's publication, etc. Another illustration of this group of transaction costs is the issue of changing a specialty or taking an academic leave of absence. In order to transfer from one faculty to another structural unit of the university, students incur high transaction costs, expressed in the loss of time devoted to fighting the "red tape". Another important component of these costs is the problem of student housing.

On the other hand, students were not much concerned with the cost of protecting property rights (0.34). These costs were mainly noted by the students of natural sciences, generating more patents and inventions than social sciences. For example, there are situations when it is difficult for students to conduct highly specialized research on the basis of their university. Also, intellectual property rights for student work are not fixed; for example, senior students and former graduates pass their materials or notes to younger students, etc. In addition, plagiarism still remains an issue, with students taking part in it. 
The costs of measurement and the costs of opportunism, in turn, were even less reflected in students' responses-0.14 and 0.13 , respectively. Students noted situations where teachers fail to use the full interactive capacity of whiteboards and sometimes show outdated slides that can be found on the Internet (even though it remains a question for a deeper discussion where slides are more useful for teaching students than the old-fashioned blackboards which make them to keep their own notes permanently throughout the lecture-it might be that students are more attentive under this scenario because they do not have presentation slides readily available in their bags or laptop). In such a situation, student have higher transaction costs from attending classes than from self-education.

With regard to the faculty and administration of universities, it becomes clear that when working at a university, faculty and university administration are faced with an expansion of the field of responsibility, resulting in an increase in transaction costs. Under such conditions, they resort to following an adaptive rationality strategy, in which actors "are prone to variable strategic action depending on existing institutions that determine the possibilities and features of obtaining and interpreting information" (Volchik and Zotova 2011).

The respondents of this group gave the highest rating to information search costs $(0.82$ and 0.64), which have many forms of expression. In particular, this is a search for orders in the university database. The reported number of database users is usually smaller than that of those actively retrieving information out of it. In addition, the publication of local regulatory acts in universities can happen in an instant or it can be adopted retroactively. The constant updating of reporting requirements for educational programs necessitates regular work with the adaptation of documents. Administrative personnel are often forced to stay at work due to unscheduled tasks and instructions.

Negotiation costs were estimated at 0.68 and 0.77 , with such a high indicator of this type of transaction cost probably being due to the high level of bureaucratization in reorganized universities. The transaction costs of negotiating appear to increase due to the practice of concluding effective contracts with teaching staff, the participation of teachers in competitions of new educational programs, or the complexity of the procedures for obtaining grants by their students. The signing of a new effective contract requires the faculty to negotiate with the personnel commission, where a decision is made on the position and a level of salary. In addition, respondents noted below the average level of negotiations and interactions between structural units of their respective universities. Among the theses expressed in in-depth interviews, all respondents who occupy administrative positions in their universities noted the lack of understanding among the teaching staff of the general course of development of their university and Russian higher education, i.e., for what purposes all the transformations and innovations occur.

In this block of the questionnaire, the maximum expert assessment was attributed to the answer to the question "How often do you encounter problems of additional approval, signing, permission, etc. in the process of your scientific and pedagogical work at the university?". In addition to this, a model of university academic mobility was implemented on the basis of SFedU and other universities, when teachers need to gain a contingent among students from other structural units and students from outside.

Among all groups of actors, it was the faculty who praised the costs of opportunism -0.67 and 0.52 , respectively. Teachers spend additional time on consultations and verification of work due to students not meeting standards at the set time. In addition, opportunism is encountered among work colleagues, which also increases this group of transaction costs.

The measurement costs were estimated at 0.41 and 0.68 . In-depth interviews showed that faculty members and administrative workers have opposing positions in assessing the frequency of educational reforms and the system of assessment of the teaching staff's performance introduced in universities. Academics talk about changing the rules of conducting educational activities too often as of a negative impact. Administrative personnel consider the process of permanent reform to be a blessing, which allows "to maintain educational activity in good shape". In general, there is a positive assessment of the point rating system for assessing students, since it acts as a motivation for students to more active 
classroom and independent work. Due to this grading system, students are forced to more evenly plan the trajectory of their studies during each semester (or module).

The costs of specifying property rights received an extremely low score of 0.21 and 0.18 , respectively. This can be interpreted not as a sign of equality of law and law enforcement practice for the protection of patents and copyrights, but rather as a lack of intellectual property rights for scientists and inventors because the results of their scientific and methodological activities are alienated by default in favor of universities. In addition, it often happens that faculty members have their research papers and reports plagiarized (i.e., using parts of them without proper acknowledgment or referencing) by students (e.g., in their theses) or by their own colleagues who use them for preparing lecture and seminar materials, in their research articles, monographs, and study guides. All of the above make many of them feel that their property rights are not observed properly and can be easily violated. When asked about the reasons for the development of these forms of plagiarism in universities, there was a change in the attitude of actors to higher education in general and a decline in the level of preparedness of students due to the result of reforms in secondary school and higher education.

\section{Designing Effective Institutions for Reorganized Universities}

Designing institutions offers important modes for the formation and functioning of universities of a new model type. This can be particularly relevant for the federal and basic universities in Russia (their distinction was explained above). In order to demonstrate that, we will use the case studies of the Southern Federal University (SFedU) and the Don State Technical University (DSTU) in the Southern Federal District of Russian Federation that became the pioneers in the implementation of universities of special status in Russia (federal and core), and were adherents of reforms to reorganize universities in the Rostov Region.

As one can see from the designated missions and program strategies of the universities that became the subject of our research, the objects of research in institutional economics are found in their formulations which determine the importance of institutional design in the development and implementation of subsequent program projects of reorganized universities (see Table 1 that follows).

Table 1. A comparison of missions and development programs of Southern Federal University (SFedU) and Don State Technical University (DSTU).

\begin{tabular}{|c|c|c|}
\hline & SFedU & DSTU \\
\hline Missions until 2020 & $\begin{array}{l}\text { Development of scientific and } \\
\text { educational and the innovation space } \\
\text { of the Southern Federal District based } \\
\text { on the generation and transfer of } \\
\text { scientific knowledge and technology, } \\
\text { the preservation and enhancement of } \\
\text { cultural traditions and values }\end{array}$ & $\begin{array}{l}\text { Creation of personnel, scientific and } \\
\text { technical capital and breakthrough } \\
\text { technologies that ensure sustainable } \\
\text { innovative and faster social and economic } \\
\text { development of the south of Russia on the } \\
\text { basis of internationalization and integration } \\
\text { of education, science and industry }\end{array}$ \\
\hline $\begin{array}{l}\text { Program goals until } \\
2020\end{array}$ & $\begin{array}{l}\text { Active participation in the production } \\
\text { of new knowledge, its dissemination } \\
\text { and use through scientific, educational } \\
\text { and innovative activities, the } \\
\text { accumulation and enhancement of } \\
\text { moral and cultural values of society, } \\
\text { the formation of a large interregional, } \\
\text { all-Russian and international center of } \\
\text { education, science and culture, as well } \\
\text { as joining number of leading } \\
\text { universities in the world }\end{array}$ & $\begin{array}{l}\text { Development of a multidisciplinary } \\
\text { research, educational and innovative } \\
\text { complex that effectively combines the } \\
\text { training of highly qualified personnel, } \\
\text { research and development with their } \\
\text { subsequent conversion to new technologies } \\
\text { in order to meet modern needs and predict } \\
\text { the socio-economic development of the } \\
\text { South of Russia to enhance the competitive } \\
\text { advantages of Rostov areas nationally and } \\
\text { internationally }\end{array}$ \\
\hline
\end{tabular}

Source: Own results derived from the Development Program of the Federal State Autonomous Educational Institution of Higher Education "Southern Federal University" for 2011-2021 (as amended in 2015); The development program of the reference university of the Rostov Region-"DSTU" for 2016-2020. 
One can see that transformations of institutions and organizational mechanisms can embody a conscious choice that purposefully forms the object and direction of the changes themselves. The project perspective implies that it is necessary to develop an institutional design in relation to what the organization seeks to achieve (its regulator or reformer), and how it is organized to achieve these goals.

\subsection{The Principle of Preservation of Education as a Mixed Good}

When it comes to describing education, the term quasi-market is often used. The specificity of this market is associated, on the one hand, with informal institutions, and, on the other hand, with a change in education as a blessing. According to Adam Smith, even if the officials did have the same interest and incentives as individuals, they could still not contribute to the flourishing of society as well because they lack the knowledge of how to do so (Smith 1822). Thence, knowledge needs proper interpretation of data and universities generate capitalized knowledge as a public good that is non-excludable and non-rivalry. Typically, educational services do not have their own price indices (even though this largely depends on the economic design of the educational system: in countries like the United States and South Korea, students have to pay tuition fees and thence educational services have a market price, while in countries like Germany or the Czech Republic, where all public schools and public universities are free from tuition fees, such a price does not exist) and are not present in the consumer basket when calculating the inflation index. This is partly due to the fact that education as a blessing has significant social functions. As was revealed in our interviews, all informants confirmed the connection of reforms in the field of education with the socio-economic development of the region, as universities prepare the engineering and managerial elite of the region. In these functions, as well as in the creation and dissemination of culture, behavioral attitudes, the social component of the university is manifested as a mixed good. The notion that higher education yields the features of both private and public goods and therefore is a "public and private good" or a "mixed good" has been proposed by some authors (Levin 1987; Hüfner 2003; Tilak 2008; Williams 2016). Thus, reorganized universities form a complex of informal institutions that should be formalized, taking into account the time lag in the labor market and in the regional economy as a whole.

\subsection{The Principle of Complementarity of Institutional Change}

The negative effects associated with the directive and highly periodic nature of institutional changes in reorganized universities lead to situations where changes in formal institutions are incoherent with informal institutions and social values. When improving and designing new institutions and mechanisms, it is very important to have a clear idea of the existing managerial routines, the institutional environment, as well as social values that are significant for actors. The development of reorganized universities is directly dependent on the implementation of performance indicators, which is a reflection of objective reality, but also with uncritical implementation, it can lead to increased bureaucratization and increased transaction costs. It should be noted that the merger of universities also stimulates their development and has a beneficial effect on those aspects of the activities of organizations that are associated with increasing returns to scale. Following the principle of complementarity of institutional changes implies maintaining existing positive incentives. Frequent changes in norms lead to a drop in interest and motivation for professional activities.

\subsection{The Principle of Transparency in Decision Making and the Diversity of Incentives}

In-depth interviews noted the lack of readiness of actors in higher education for high-period changes in universities. Russia has a unique experience in transformations, since most of the higher education institutions are similar state organizations with vertical management. The hierarchical structure of education implies the implementation of decisions obtained from above, which often contradict each other: "I do not see a single policy pursued in the education system. I see a contradiction between the goals set and the tools used" (Associate Professor, 43 years old). The initiators of the changes, 
the decision-making process and the benefits derived from this remain far from public discussion. The developers of reforms in higher education remain unknown and are not responsible for the decisions made. In order to overcome the managerial chaos and reduce bureaucratic pressure from education and science officials, it is necessary to follow the principle of transparency of decision-making. This implies a comprehensive examination and public discussion of upcoming reforms, as well as the revival of the reputation mechanism through the personification of the initiators and beneficiaries of the changes. Figure 3 shows the hierarchy of the principles of institutional design. It is apparent that these principles should be comprehensively implemented at all levels of the scientific and educational system.

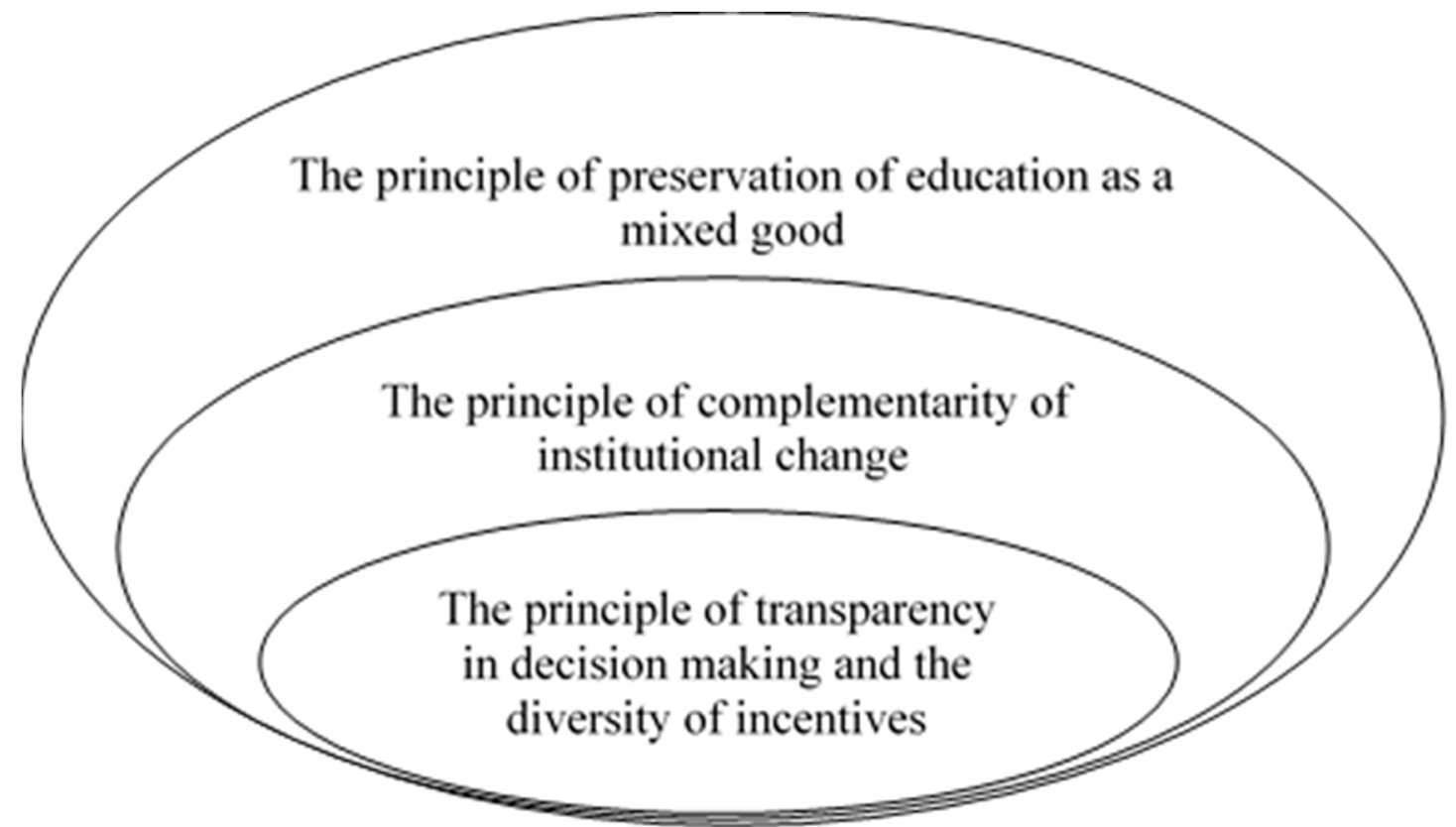

Figure 3. The hierarchy of principles of institutional design of higher education and science. Source: own results.

Our results obtained from the in-depth interviews show that there is no practical systematic understanding of reforms expressed in the disorganization of managerial routines, the destruction of existing incentives and motivation, bureaucratization and prolongation of activities. All of these ultimately lead to an increase in transaction costs.

We think that the proposed principles should be comprehensively implemented at all levels of the scientific and educational system. The most general principle of preserving education as a mixed good presupposes a consensus in society on the ratio of public and private spending on education and science. The principle of transparency of decision-making refers to the intra-organizational level and can be implemented in the activities of individual universities and the policymakers at the national level. The implementation of the principle of complementarity of institutional changes is impossible without the implementation of the previous ones. On the one hand, an understanding of how the existing institutes of education and science function is obtained (and this requires a dialogue with all actors of scientific and educational activities), and on the other hand, it implies the existence of a single and stable image of the results of reforms (which cannot be formed in the absence of an understanding of the role and places of higher education in society).

\section{Conclusions}

Overall, it becomes obvious that the state policy in the field of higher education and science should include a substantial revision of the role of the university and higher education in society. Traditional universities performed the function of a providing personnel with required skills due to 
the formation of knowledge and competencies necessary for the requirements of the labor market (i.e., university representing a resource). Now, the reformed universities are faced with new challenges demanding them to provide skills that would introduce innovations in the educational process and transform institutions and behavioral patterns (i.e., the university being a driver of development). All of the above features are very important for the leading role and position of the universities in every economy. It is true that in the 1980s and early 1990s, higher educational institutions (in particular in socialist countries) were not primarily interested in preparing employees for the job market. In those days, a university degree was simply regarded as a positive signal for potential employers. However, nowadays the situation is somewhat different. This is particularly apparent in the case of Russia, where the economic transformation of the 1990s and early 2000s gave rise to a plethora of university graduates with economics and law degrees which struggled to find jobs. As a result, Russian stakeholders and policymakers started a cooperation with the universities, asking them to concentrate on working closer with potential employers and preparing specialists in the fields which were demanded by the labor market. As a result, many study programs underwent profound changes and became more practically oriented (even though the results of this process were of varying quality).

Our results stemming from the questionnaires and in-depth interviews with actors from the reorganized universities of the Rostov Region in the Russian Federation reveal the centralization of managerial hierarchies and a decrease in the autonomy of universities, a decrease in academic freedoms and tightening control over the activities of the university and its faculty through the target system. In addition, we carried out the analysis of the dynamics of transaction costs of the main groups of actors of the educational process. The adaptive rationality of the faculty is due to the expansion of the area of responsibility and is expressed in the tendency towards a variable strategic action depending on the existing institutions that determine the possibilities and features of obtaining and interpreting information. For this group of actors, the transaction costs of measuring and negotiating prevail, while the students surveyed noted the costs of searching and finding the right information. In the era of the digital economy, new educational technologies should increase the efficiency of knowledge transfer, and not become a daily routine for meeting targets. The vertical reorganization of universities contradicts the inclusiveness of institutions which provides the ability to evolutionary change.

Our results show that a well-balanced economic institutional design is required for the sustainable development of reorganized leading universities. It becomes apparent that the purpose of any higher education institution that, on the one hand, remains independent of the state, and, on the other hand, has to follow state higher education policy with its state funding might be crucial to achieve the sustainable development goals.

One would probably agree with the fact that private universities with shareholder models care about shareholder dividends and can be seen as the worrying trend when some of them go bankrupt after the student fees are directed to shareholder dividends and students are left with huge debt and registered in courses that are closed before they have the chance to complete them. Therefore, the institutional design needs to be made transparent and this is what is required to be monitored by an independent legislator that would ensure the highest of standards in elite institutions of higher education, in Russia or elsewhere.

Our findings can be translated into the basic principles of the design of effective institutions of universities that are undergoing reforms or reorganization due to the attempts to increase effectiveness or adjust to the new technological trends and the observance of them can be recommended when conducting educational reforms in general. We think that the preservation of education as a mixed blessing, the complementarity of organizational and institutional changes, transparency in decision-making and the variety of incentives for all the actors involved in this process should help reduce transaction costs in the basic fields of activity of higher education institutions.

Author Contributions: Conceptualization, V.V., A.M., P.S., W.S.; methodology, V.V., and W.S.; formal analysis, V.V., A.M., P.S.; investigation, A.M., P.S.; resources, W.S.; data curation, V.V., A.M., P.S.; writing—original draft 
preparation, V.V., W.S.; supervision, V.V.; project administration, V.V., A.M., P.S., W.S.; funding acquisition, V.V., A.M., P.S. All authors have read and agreed to the published version of the manuscript.

Funding: This paper is supported by the Ministry of Education and Science of the Russian Federation, Project No. 26.6124.2017/8.9 "Identification of institutions and organizational mechanisms for the merger of universities in the context of the socio-economic development of the region".

Conflicts of Interest: The authors declare no conflict of interest.

\section{References}

Ansel, Ben W. 2008. University Challenges: Explaining Institutional Change in Higher Education. World Politics 60: 189-230. [CrossRef]

Babintsev, Valentin P., Viktor Sapryka, Yana I. Serkina, and Galina F. Ushamirskaya. 2016. Reform of Higher Education in Russia: Habitus Conflict. European Journal of Contemporary Education 17: 284-94. [CrossRef]

Bhardwaj, Ravinder K., and Leroy D. Brooks. 1992. The January anomaly: Effects of low share price, transaction costs, and the bid-ask bias. Journal of Finance 47: 553-74. [CrossRef]

Bigelow, Lyda, Jackson A. Nickerson, and Woo-Yong Park. 2019. When and how to shift gears: Dynamic trade-offs among adjustment, opportunity, and transaction costs in response to an innovation shock. Strategic Management Journal 40: 377-407. [CrossRef]

Bileviciute, Egle, Romualdas Draksas, Andrius Nevera, and Milda Vainiute. 2019. Competitiveness in Higher Education: The Case of University Management. Journal of Competitiveness 11: 5-21. [CrossRef]

Bogoviz, Aleksei V., Alexandr V. Gimelshteyn, Evgeny E. Shvakov, Elena V. Maslova, and Anna A. Kolosova. 2018. Digitalization of the Russian education system: Opportunities and perspectives. Quality-Access to Success 19: 27-32.

Boyce, Gavin, Angela Greenwood, Amy Haworth, Jacky Hodgson, Chris Jones, Gary Marsh, Maria Mawson, and Rosa Sadler. 2019. Visions of value: Leading the development of a view of the university library in the 21st century. The Journal of Academic Librarianship 45: 102046. [CrossRef]

Clément, Karine. 2019. Social mobilizations and the question of social justice in contemporary Russia. Globalizations 16: 155-69. [CrossRef]

Coates, Hamish, Paula Kelly, Ryan Naylor, and Victor Borden. 2016. Innovative approaches for enhancing the 21st century student experience. Alternation Journal 23: 62-89.

Collini, Stefan. 2012. What Are Universities for? London: Penguin.

De Boer, Harry, Jürgen Enders, and Uwe Schimank. 2007. On the way towards new public management? The governance of university systems in England, the Netherlands, Austria, and Germany. In New Forms of Governance in Research Organizations. Dordrecht: Springer, pp. 137-52. [CrossRef]

De Boer, Harry F., Jürgen Enders, and Uwe Schimank. 2008. Comparing higher education governance systems in four European countries. In Governance and Performance of Education Systems. Dordrecht: Springer, pp. 35-54. [CrossRef]

Demsetz, Harold. 1968. Cost of Transacting. Quarterly Journal of Economics 83: 33-53. [CrossRef]

Ferlie, Ewan, Christine Musselin, and Gianluca Andresani. 2008. The steering of higher education systems: A public management perspective. Higher Education 56: 325. [CrossRef]

Francesconi, Marco, Fabián Slonimczyk, and Anna Yurko. 2019. Democratizing access to higher education in Russia: The consequences of the unified state exam reform. European Economic Review 117: 56-82. [CrossRef]

Ganev, Venelin I. 2005. The "triumph of neoliberalism" reconsidered: Critical remarks on ideas-centered analyses of political and economic change in post-communism. East European Politics and Societies 19: 343-78. [CrossRef]

Hemment, Julie. 2009. Soviet-style neoliberalism? Nashi, youth voluntarism, and the restructuring of social welfare in Russia. Problems of Post-Communism 56: 36-50. [CrossRef]

Holmberg, Daniel, and Olof Hallonsten. 2015. Policy reform and academic drift: Research mission and institutional legitimacy in the development of the Swedish higher education system 1977-2012. European Journal of Higher Education 5: 181-96. [CrossRef]

Hüfner, Klaus. 2003. Higher education as a public good: Means and forms of provision. Higher Education in Europe 28: 339-48. [CrossRef]

Jongbloed, Ben, Jürgen Enders, and Carlo Salerno. 2008. Higher education and its communities: Interconnections, interdependencies and a research agenda. Higher Education 56: 303-24. [CrossRef] 
Jouan, Julia, Aude Ridier, and Matthieu Carof. 2019. Economic Drivers of Legume Production: Approached via Opportunity Costs and Transaction Costs. Sustainability 11: 705. [CrossRef]

Kotiev, George O., Boris V. Padalkin, Alexander B. Kartashov, and Alex S. Diakov. 2017. Designs and development of Russian scientific schools in the field of cross-country ground vehicles building. ARPN Journal of Engineering and Applied Sciences 12: 1064-71.

Levin, Henry M. 1987. Education as a public and private good. Journal of Policy Analysis and Management 628-41. [CrossRef]

Loomis, S., and J. Rodriguez. 2009. Institutional Change and Higher Education. Higher Education 58: 475-89. [CrossRef]

Meinlschmidt, Jan, Martin C. Schleper, and Kai Foerstl. 2018. Tackling the sustainability iceberg: A transaction cost economics approach to lower tier sustainability management. International Journal of Operations $\mathcal{E}$ Production Management 38: 1888-914. [CrossRef]

Ministry of Science and Higher Education of the Russian Federation. 2020. Russian Academic Excellence Project. Available online: https://www.5top100.ru/en/ (accessed on 15 February 2020).

Möller, Torger. 2018. Same objectives, different governance-how the excellence initiative and the pact for research and innovation affect the German science system. Fteval Journal for Research and Technology Policy Evaluation 45: 4-8. [CrossRef]

North, Douglas, and John J. Wallis. 1986. Measuring the Transaction Sector in the American Economy, 1870-970/Long-term factors in American Economic Growth. Edited by Engermann S. and Gallman R. Chicago: University of Chicago Press, pp. 95-161.

Payne, Emily Miller, Russ Hodges, and Elda Patricia Hernandez. 2017. Changing Demographics and Needs Assessment for Learning Centers in the 21st Century. Learning Assistance Review 22: 21-36.

Pesch, Udo, and Georgy Ishmaev. 2019. Fictions and frictions: Promises, transaction costs and the innovation of network technologies. Social Studies of Science 49: 264-277. [CrossRef] [PubMed]

Ren, Shuang, Ying Zhu, and Malcolm Warner. 2017. Dilemmas concerning the employment of university graduates in China. Studies in Higher Education 42: 551-71. [CrossRef]

Rodionov, Dmitriy Grigorievich, Natalia Gennadievna Fersman, and Olga Alexandrovna Kushneva. 2016. Russian Universities: Towards Ambitious Goals. International Journal of Environmental and Science Education 11: 2207-22.

Rutland, Peter. 2013. Neoliberalism and the Russian transition. Review of International Political Economy 20: 332-62. [CrossRef]

Schubert, Torben. 2009. Empirical observations on New Public Management to increase efficiency in public research-Boon or bane? Research Policy 38: 1225-34. [CrossRef]

Shersheva, M., ed. 2017. Institutional Changes in the Social Sphere of Russian Regions. Moscow: Moscow State University Press, Available online: https:/www.econ.msu.ru/sys/raw.php?o=38052\&p=attachment (accessed on 20 November 2019).

Smith, A. 1822. The Wealth of Nations. Edited by J. Richardson. Cambridge: MIT Press.

Stoll, Hans R., and Robert E. Whaley. 1983. Transaction costs and the small firm effect. Journal of Financial Economics 12: 57-79. [CrossRef]

Tahar, Sadri, and Roman Boutellier. 2013. Resource Allocation in Higher Education in the Context of New Public Management. Public Management Review 15: 687-711. [CrossRef]

Tambovtsev, V. L. 2015. Social policy: The unsolved problem of scientific justification. Social Sciences and the Present 6: 5-13.

Taysum, Alison. 2019. Education Policy as a Road Map to Achieving the Sustainable Development Goals. Scarborough: Emerald.

Tilak, Jandhyala B. 2008. Higher education: A public good or a commodity for trade? Prospects 38: 449-66. [CrossRef]

Valeeva, Roza A., and Ilshat R. Gafurov. 2017. Initial teacher education in Russia: Connecting theory, practice and research. European Journal of Teacher Education 40: 342-60. [CrossRef]

Veblen, Thorstein. 1899. The Theory of the Leisure Class: An Economic Study in the Evolution of Institutions. Macmillan: NYC.

Volchik, Vyacheslav, and A. A. Oganesyan. 2014. Why do we need an old institutional economics, if there is neoinstitutionalism? Terra Economicus 12: 79-90. 
Volchik, Vyacheslav, and Tatyana Zotova. 2011. Adaptive rationality and economic behavior in the evolutionary context. Terra Economicus 9: 54-64.

Volchik, Vyacheslav, A. A. Zhuk, and M. A. Korytsev. 2017. Competitive environment of the market of higher education in the Rostov region. Terra Economicus 15: 178-96. [CrossRef]

Volchik, Vyacheslav V., Pavel O. Savko, and Artyom I. Maskaev. 2018. Complementarities between Institutional and Organizational Change in the Context of Academic Reorganization. Journal of Institutional Studies 10: 156-72. [CrossRef]

Williams, Gareth. 2016. Higher education: Public good or private commodity? London Review of Education 14: 131-42. [CrossRef]

Williamson, Oliver. 1993. Opportunism and its Critics. Managerial and Decision Economics 14: 97-107. [CrossRef]

Zapp, Mike, and Francisco O. Ramirez. 2019. Beyond internationalisation and isomorphism-the construction of a global higher education regime. Comparative Education 55: 473-93. [CrossRef]

(C) 2020 by the authors. Licensee MDPI, Basel, Switzerland. This article is an open access article distributed under the terms and conditions of the Creative Commons Attribution (CC BY) license (http://creativecommons.org/licenses/by/4.0/). 